\title{
Monitoring Tool for Water Quality and Quick Alert of Flooding
}

Armando Rodríguez Rodriguez / arrodriguez@upr.edu.cu

José R. Vento Álvarez, Ph.D / vento@upr.edu.cu

Jorge Garrido González, MsC / jgarrido@upr.edu.cu

Vicente Rodríguez Benitez, MSc. / vicente@upr.edu.cu

Universidad de Pinar del Río, Cuba

ABSTRACT In July 2010, the United Nations General Assembly explicitly recognized the human right to water and sanitation, reaffirming that clean drinking water is essential for the realization of all the human rights. Therefore, controlling water quality should be a priority. In this context, it is interesting to make a simple, sustainable and low-cost system, in order take control over water quality parameters. This project main goal is to design and implement a water quality monitoring system on distribution networks to population or another interesting environment. It incorporates a quick alert system of flooding on low-altitude zones. It has mobile communication interface, over GSM, GPRS or 3G network, to send alarm and monitoring signals.

KEYWORDS Sensors; water quality control; potability, Arduino; electrical conductivity; turbidity.

Herramienta de monitoreo de la calidad del agua y alerta temprana ante inundaciones

RESUMEN En julio de 2010, la Asamblea General de las Naciones Unidas reconoció el derecho humano al agua y al saneamiento, reafirmando que el acceso a agua potable limpia es esencial para la realización de todos los derechos humanos. Por lo tanto, controlar la calidad del agua debe ser una prioridad. En este marco, es interesante realizar un sistema sencillo, sostenible y de bajo costo, que facilite el control de los parámetros de calidad del agua. El objetivo general de este trabajo es diseñar e implementar un sistema de de monitoreo de la calidad del agua en redes de distribución a la población u otros escenarios donde sea necesaria analizar la potabilidad de la misma. Además, incorpora un sistema de alerta ante la posible inundación de los embalses en zonas bajas o de interés general. Dispone de una interfaz de comunicaciones móviles, soportado sobre la red GSM, GPRS y 3G, para el envío de señales de monitoreo y alarma.

PALABRAS CLAVE Sensores; control de calidad del agua; potabilidad; Arduino; conductividad eléctrica; turbidez.
Ferramenta de monitoramento da qualidade da água e aviso de risco de inundaçãoF

RESUMO Em julho de 2010, a Assembleia Geral das Nações Unidas reconheceu o direito humano à água e ao saneamento, reafirmando que o acesso a água potável limpa é essencial para a realização de todos os direitos humanos. Portanto, controlar a qualidade da água deve ser uma prioridade. Neste contexto, é interessante realizar um sistema simples, sustentável e de baixo custo que facilite o controle dos parâmetros de qualidade da água. O objetivo geral deste trabalho é projetar e implementar um sistema de monitoramento da qualidade da água em redes de distribuição para a população ou outros cenários onde seja necessário analisar a potabilidade da mesma. Além disso, incorpora um sistema de alerta para a possível inundação de reservatórios em áreas baixas ou áreas de interesse geral. Possui uma interface de comunicações móveis, suportada na rede GSM, GPRS e 3G, para o envio de sinais de monitoramento e alarme.

PALAVRAS-CHAVE Sensores; controle de qualidade da água; potabilidade; Arduino; condutividade elétrica; turbidez. 


\section{Introduction}

During the last years, there has been an attempt, from different organisms, to raise awareness about the importance of access to drinking water throughout the world. Thus, in July 2010, the General Assembly of the United Nations explicitly recognized the human right to water and sanitation, reaffirming that drinking water is essential in the realization of all human rights. The intention was that both civil society and states devote a part of their time or budget trying to ensure that this right is fulfilled throughout the world, both in urban and rural areas, both in developed and developing countries.

However, according to data from the United Nations $[\mathrm{UN}]$ and the Joint Monitoring Program for Water Supply and Sanitation of the World Health Organization [WHO] and the United Nations Children's Fund [UNICEF] (2015), more than three and a half million people die each year due to problems related to the quality of the water they drink or sanitation and hygiene issues. The vast majority of these deaths occur in developing countries, where access to drinking water is very limited and at the same time poorly controlled by the government and regulations, generally due to lack of resources. Therefore, controlling water quality should be a priority.

To measure the water potability there are different parameters that are traditionally used in the field of water quality control: potential of hydrogen, electrical conductivity, turbidity, temperature, oxidation/reduction potential, chemical parameters and microbiological parameters.

The potential of Hydrogen $(\mathrm{pH})$ is a measure of acidity or alkalinity of a solution that indicates the amount of hydrogen ions present in the water. Uses a logarithmic scale from 0 to 14 . As for water, limits can be set, depending on each regulation, in which water is too acidic or too alkaline to be potable.

Electrical Conductivity [EG] is the measure of the ability of a material or substance to let the electric current pass freely. Its unit of measurement are the Siemens/ meter $[\mathrm{S} / \mathrm{m}]$, the inverse of the resistance in ohms per meter. It is a simple measure to determine the water quality because, unlike the $\mathrm{pH}$, it only has an upper limit, that is, if it has conductivity tending to 0 , the water is of good quality, and if it reaches a limit determined by the regulations, it is no longer potable.

It is important to know the water temperature, since too high temperature facilitates the development of

\section{Introducción}

Durante los últimos años se ha intentado, desde diferentes organismos, crear conciencia acerca de la importancia del acceso al agua potable en todo el mundo. De esa manera, en julio de 2010, la Asamblea General de las Naciones Unidas reconoció de manera explícita el derecho humano al agua y al saneamiento, reafirmando que un agua potable es esencial en la realización de todos los derechos humanos. La intención era que, tanto la sociedad civil, como los Estados, dediquen una parte de su tiempo o presupuesto a intentar que ese derecho se cumpla en todo el mundo, tanto en zonas urbanas, como rurales, tanto en países desarrollados, como en países en desarrollo.

No obstante, según datos de la Organización de las Naciones Unidas [ONU] y del Foint Monitoring Program for Water Supply and Sanitation de la Organización Mundial de la Salud [World Heath Organization, WHO ] y el Fondo de las Naciones Unidas para la Infancia [The United Nations Children's Fund, UNICEF] (2015), más de tres millones y medio de personas mueren al año por problemas derivados de la calidad del agua que beben o de saneamiento e higiene. La gran mayoría de estas muertes se produce en los países en desarrollo, donde el acceso al agua potable está muy limitado y a la vez poco controlado por el gobierno y las normativas, generalmente por falta de recursos. Por ello, controlar la calidad del agua debe ser una prioridad.

Para medir la potabilidad del agua hay diferentes parámetros que se utilizan tradicionalmente en el campo del control de la calidad del agua: potencial hidrógeno, electro conductividad, turbidez, temperatura, potencia de oxidación/reducción, parámetros químicos y parámetros microbiológicos.

El potencial Hidrógeno $(\mathrm{pH})$ es una medida de acidez o alcalinidad de una solución que indica la cantidad de iones hidrógeno presentes en el agua. Utiliza una escala logarítmica de $0 \mathrm{a}$ 14. En cuanto al agua, se puede poner unos límites, dependientes de cada normativa, en los que un agua es demasiado ácida o demasiado alcalina para ser potable.

La Electro Conductividad [EG] es la medida de la capacidad de un material o sustancia para dejar pasar libremente la corriente eléctrica. Su unidad de medida son los Siemens/metro $[\mathrm{S} / \mathrm{m}]$, la inversa de la resistencia en ohmios por metro. Es una medida simple para determinar la calidad del agua porque, a diferencia del $\mathrm{pH}$, solo tiene un límite superior, es decir, si tiene conductividad tendiente a 0 , el agua es de buena calidad, y si llega a un límite determinado por la normativa, ya no es potable.

Es importante conocer la temperatura a la que se encuentra el agua, puesto que una temperatura demasiado alta facilita el desarrollo de bacterias en el agua. Además, es importante a la hora de realizar la calibración de otros parámetros, por lo que siempre es necesario conocer la temperatura del agua de la que se está comprobando la potabilidad.

La turbidez es la falta de transparencia de un líquido debido a la presencia de partículas en suspensión. Cuanto más turbia es el agua, menor es su calidad. La unidad internacional de medida es la Unidad Nefelométrica de Turbidez [NTU, Nephe- 
lometric Turbidity Units] aunque también es utilizada, como unidad de medida, el número de (ppm, parts per million).

El Potencial de Oxidación/Reducción [ORP, Oxidation/Reduction Potential) es como se conoce a la tendencia de las especies químicas en una reacción redox [reducción/oxidación] o de un electrodo en una celda galvánica, a adquirir electrones. Se utiliza generalmente para medir la calidad del agua. Un ORP de 650 $\mathrm{mV}$ desactiva casi cualquier virus presente en ella.

Los parámetros químicos utilizados son la concentración de arsénico, cobre, plomo y otros que tienen un límite para determinar su calidad; los parámetros microbiológicos se refieren a conteos de colonias a 22 o 37 grados, y la concentración de ciertos tipos de bacterias, como Escherichia coli y Enterococcus.

El sistema propuesto realiza un análisis de la calidad del agua corriente a partir de una sonda o sensor desarrollado e implementado a tal fin, cuyo principio de funcionamiento radica en la caracterización de la conductividad eléctrica de la misma. Es conocido que, a mayores indicadores de este parámetro, la calidad del agua es peor, y por ende, menor su potabilidad. A su vez, este sensor chequea la altura del nivel del agua y construye un historial, con el fin de determinar comportamientos futuros de acuerdo con análisis probabilísticos.

En cuanto a la calidad del agua, este proyecto se basa en la estandarización establecida por la Organización Mundial de la Salud (2006), que define los límites para la mayoría de las sustancias que puedan estar presentes, en función del grado de concentración y sus efectos en la salud humana.

\section{Estado del arte}

En el marco de proyectos de cooperación se han realizado durante años algunos más o menos grandes relacionados con el control de la calidad del agua. Existen tres características comunes en la mayor parte de los éstos:

- Proyectos Open Source/Open Hardware: es importante que el código que se genere sea libre, así como que los datos del hardware utilizado y de los diferentes diagramas de bloques del sistema completo, para que otros proyectos lo puedan replicar o tomar como base para un primer prototipo en otro proyecto.

- Proyectos surgidos del ámbito académico: ya surjan de la colaboración con organismos de cooperación o por iniciativa propia de un grupo de investigación, la mayor parte de estos surgen y se desarrollan en las universidades.

- Proyectos colaborativos y multidisciplinarios: es dificil y largo que una sola persona realice un proyecto de estas características, por lo que se suelen dividir en bloques, manteniendo una fuerte comunicación entre ellos para conseguir un buen resultado.

En el ámbito de los proyectos de cooperación para la motorización de la calidad del agua hemos encontrado tres proyectos interesantes para estudiar y tomar como referencia en el diseño de nuestro propio sistema. A continuación vamos a detallarlos, se trata de los proyectos: Riffle (Warren, 2017), Low-cost Autonomous Water Quality Monitoring System (Gertz \& Di Justo, 2012) y Mae d'agua (VJ-Pixel, 2017). bacteria in the water. In addition, it is important when carrying out the calibration of other parameters, so it is always necessary to know the temperature of the water from which potability is being checked.

Turbidity is the lack of transparency of a fluid due to the presence of particles in suspension. The more cloudy the water, the lower its quality. The international unit of measurement is the Nephelometric Turbidity Unit [NTU], although the number of parts per million is also used as a unit of measurement [ppm]

The Oxidation/Reduction Potential [ORP] is the tendency of a chemical species in a redox reaction [reduction/ oxidation] or an electrode in a galvanic cell to acquire electrons. It is usually used to measure the water quality. An ORP of $650 \mathrm{mV}$ deactivates almost any virus present in it.

The chemical parameters used are: concentration of arsenic, copper, lead and others that have a limit to determine their quality; the microbiological parameters refer to colony counts at 22 or 37 degrees, and the concentration of certain types of bacteria, such as Escherichia coli and Enterococcus.

The proposed system performs an analysis of the water quality from a probe or sensor developed and implemented for that purpose, whose principle of operation lies in the characterization of the electrical conductivity thereof. It is known that, the greater indicators of this parameter, the worse the quality of the water, and therefore, less potability. In turn, this sensor checks the height of the water level and builds a history, in order to determine future behaviors according to probabilistic analysis.

About water quality, this project is based on standardization established by the World Health Organization (OMS, 2006), which defines the limits for most substances that may be present, depending on the degree of concentration and its effects on human health.

\section{State of the Art}

Within the framework of cooperation projects, some more or less large ones related to the control of water quality have been carried out.

There are three common characteristics in most of these:

- Open Source/Open Hardware projects: it is important that the code generated is free, as well as the data of the hardware used and the different block diagrams of the complete system, so that 
other projects can replicate it or take it as a basis for a first prototype in another project.

- Projects arising from the academic field: whether they arise from collaboration with cooperation organizations or from the initiative of a research group, most of them arise and are developed in universities.

- Collaborative and multidisciplinary projects: it is difficult and long for a single person to carry out a project of these characteristics, which is why they are usually divided into blocks, maintaining a strong communication between them to achieve a good result.

In the area of cooperation projects for the motorization of water quality, we have found three interesting projects to study and take as reference in the design of our own system. Next, we are going to detail them as follows: Riffle (Warren, 2017), Low-cost Autonomous Water Quality Monitoring System (Gertz \& Di Justo, 2012) and Mae d'agua (VJ-Pixel, 2017).

Riffle is a collection of designers for an open source approach for water monitoring. The original design of this project was a data collector plate based on ARM processors encapsulated in PVC; PublicLab has supported the development of another compiler based on Atmel328 processor encapsulated in a water bottle.

Low-cost Autonomous Water Quality Monitoring System is a compilation of projects based on free hardware and software platforms, such as Arduino and Xbee, focused on acquisition of environmental variables. It describes, in a pleasant and clear way, a new point of view for understanding of natural phenomena surrounding us, establishing an interactive and motivational dialogue for the public in the field of development of reconfigurable hardware applications.

The Rede InfoAmazonia project is developing Mãe d'água [Mother of Water], a real time water quality monitoring tool based on free hardware. Its objective is to detect possible contaminations, such as sewage water, industrial toxins and heavy metals in water.

The system will help to accurately infer the physicochemical properties and variables that distinguish contaminated water from drinking water.

The device will measure the acidity of water through $\mathrm{pH}$, ORP, conductivity, temperature and barometric pressure at the water level, which are factors required for assessing quality of water for human consumption.
Riffle es una colección de diseñadores para un enfoque de código abierto para la monitorizacion del agua. El diseño original de este proyecto fue una placa recopiladora de datos basado en procesadores ARM encapsulados en PVC; PublicLab ha apoyado el desarrollo de otro recopildador basado en procesador Atmel328 encapsulados en una botella de agua.

Low-cost Autonomous Water Quality Monitoring System es una compilación de proyectos basados en plataformas de hardware y software libre, como Arduino y Xbee, enfocadas en la adquisición de variables ambientales. Describe de forma amena y clara un nuevo punto de vista en la comprensión de los fenómenos naturales que nos rodean, estableciendo un dialogo interactivo y motivacional para el público en el ámbito de desarrollo de aplicaciones de hardware reconfigurable.

El proyecto Rede InfoAmazonia está desarrollando Mãe d'água [Madre del Agua], un monitor de calidad de agua en tiempo real, basado en hardware libre. Su objetivo es detectar posibles contaminaciones, tales como aguas albañales, toxinas industriales y metales pesados en el agua. El sistema ayudará a inferir con exactitud las propiedades fisicoquímicas y las variables que distinguen el agua contaminada de la potable.

El dispositivo medirá la acidez del agua mediante el pH, el ORP, la conductividad, la temperatura y la presión barométrica en el nivel de agua, que son factores para considerar a la hora de evaluar la calidad del agua para consumo humano.

\section{Diseño e implementación}

\section{A. Descripción modular \\ Microcontrolador}

La elección del micro-controlador es una decisión importante en cualquier proyecto electrónico, de él depende el resto del sistema y, por tanto, hay ciertos requisitos que se deben cumplir para que el sistema funcione correctamente.

Esos requisitos suelen ser de memoria, de números de pines o que sea capaz de implementar de forma sencilla protocolos de comunicación tales como: Universal Anynchronous Receiver-Transmitter [UART], Pulse-Width Modulation [PWM], Inter-integrated Circuit (o comunicaciones por I2G) o Serial Peripheral Interface [SPI.

En el caso de este proyecto, un requisito muy importante, además de los ya mencionados, es la reproducibilidad del sistema. Para ello se ha decidido optar por hardware Open Source, para de esta manera facilitar el desarrollo y mejora futura del proyecto. Por ello, en primer lugar se decidió optar por una placa Arduino, que ofrece un rendimiento muy bueno y tiene un coste reducido.

Puesto que el módulo de sensores no requiere de mucha memoria, inicialmente se pensó en la posibilidad de utilizar un Arduino Uno, pero la existencia del módulo de comunicaciones para procesar y enviar los datos volvía más estricto el requisito de memoria.

Además, se necesitan muchos pines, tanto analógicos, como digitales, para los diferentes sensores, y al ser un proyecto abierto, los pines en exceso pueden ser utilizados en un futuro para mejorar el sistema añadiendo sensores o funcionalidades. 


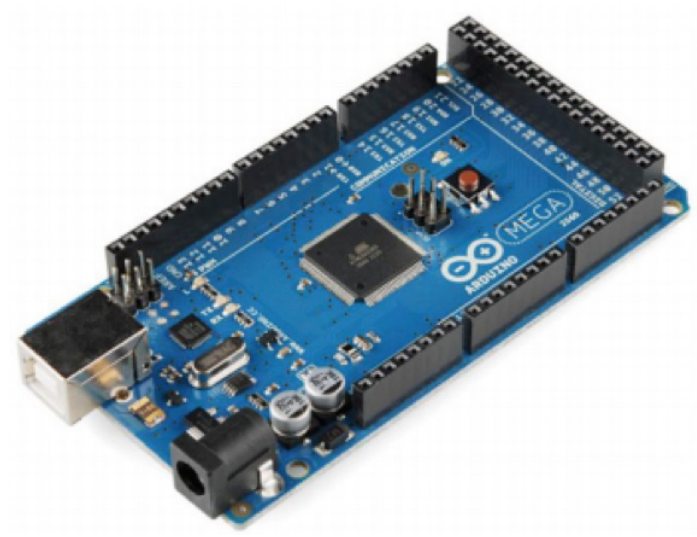

Figure 1. Arduino Mega 2560

Por esta razón la decisión final fue utilizar un Arduino Mega 2560 (Figura 1) que cuenta con un micro-controlador ATmega2560.

Las especificaciones más importantes de la placa son (Arduino, 2018):

- memoria RAM de 8kb. Aunque no se ha realizado una estimación, teniendo en cuenta las elecciones de microcontrolador en los proyectos mencionados, esta memoria es más que suficiente para nuestro requisito;

- 54 entradas/salidas digitales, de las cuales 14 se pueden utilizar como salida de una señal PWM y 16 como entradas analógicas, de esta manera, no se va a tener que hacer especial esfuerzo en ahorrar pines a la hora de decidir sensores u otros sub-módulos;

- fácilmente programable con el IDE de Arduino, lo que facilita la labor de generación de código, al ser un lenguaje de programación derivado de $\mathrm{C}$ pero con múltiples librerías internas;

- funciona a $5.0 \mathrm{v}$, lo que viene muy bien para los sensores que se van a utilizar;

- cuenta con puertos serie (UART), un oscilador de 16 $\mathrm{MHz}$, un conector USB (para cargar el programa desde el ordenador), un conector de alimentación y un pulsador para reiniciar manualmente el sistema sin necesidad de volver a cargarlo a través de la interfaz USB.

\section{Módulo sensor conductividad eléctrica}

La conductividad eléctrica es un parámetro muy importante a la hora de medir la calidad del agua. En efecto, generalmente, cuantas más sustancias hay disueltas en una muestra de agua, más electricidad conduce. Sin embargo, en el mercado los sensores de conductividad eléctrica en el agua suelen rondar los US\$ 80, un precio por el cual no tendría sentido utilizarlos en este proyecto. Por eso, se ha optado por otra solución: fabricar una sonda de conductividad eléctrica cuyo coste no supera los $\mathrm{US} \$ 5$.

La fabricación de este dispositivo es muy sencilla: simplemente se necesita un enchufe típico que al otro lado tenga dos cables separados, como se observa en la Figura 2. Cada uno de

\section{Design and Implementation}

\section{A. Modular Description Microcontroller}

The choice of the micro-controller is an important decision in any electronic project, the rest of the system depends on it and, therefore, there are certain requirements that must be met in order for the system to work properly. These requirements are usually of memory, pin numbers or anything that is able to easily implement communication protocols such as: Universal Anynchronous Receiver-Transmitter [UART], Pulse-Width Modulation [PWM], Inter-integrated Circuit (or communications by I2C) or Serial Peripheral Interface [SPI].

In the case of this project, a very important requirement, besides those already mentioned, is the reproducibility of the system. For this, it has been decided to opt for Open Source hardware, in order to facilitate the development and future improvement of the project. Therefore, in the first place it was decided to opt for an Arduino board, which offers a very good performance and has a reduced cost.

Since the sensor module does not require a lot of memory, the possibility of using an Arduino Uno was initially considered, but the existence of the communications module to process and send the data tightened the memory requirement. In addition, many pins are needed, both analog and digital, for the different sensors, and being an open project, the excess pins can be used in the future to improve the system by adding sensors or functionalities. For this reason, the final decision was to use an Arduino Mega 2560 (FIgure 1) that has an ATmega2560 micro-controller. The most important specifications of the board are (Arduino, 2018):

- 8kb RAM memory. Although an estimate has not been made, taking into account the choices of microcontroller in the mentioned projects, this memory is more than sufficient for our requirement;

- 54 digital inputs/outputs, of which 14 can be used as output of a PWM signal and 16 as analog inputs, so it is no necessary to make special effort to save pins when deciding sensors or other sub-modules;

- easily programmable with the Arduino IDE, which facilitates the work of code generation, since it is a programming language derived from $\mathrm{C}$ but with multiple internal libraries; 
- works at $5.0 \mathrm{v}$, which is very good for the sensors that will be used;

- it has serial ports (UART), a $16 \mathrm{MHz}$ oscillator, a USB connector (to load the program from the computer), a power connector and a button to manually restart the system without having to reload it through the USB interface.

\section{Electrical Conductivity Sensor Module}

Electrical conductivity is a very important parameter when measuring water quality. In effect, generally, the more substances are dissolved in a water sample, the more electricity it conducts. However, in the market the sensors of electrical conductivity in water are usually around US \$80, a price for which it would not make sense to use them in this project. For that reason, another solution has been chosen: manufacturing an electrical conductivity probe whose cost does not exceed US $\$ 5$.

The manufacturing of this device is very simple: it is necessary a typical plug that has two separate cables on the other side, as shown in Figure 2. Each one of these cables is connected to an electrode of the plug on one side, and the Arduino on the other side, in this way the plug will work as a probe in the water and the information of the electrical conductivity can be extracted from the values read on the cables. The only thing that has to be added for the connection are two Arduino cables so that the ends are compatible with the board. For its connection with Arduino, the indications given by Gertz and Di-Justo (2012) have been followed. The result of the connection is relatively simple, as can be seen in Figure 3:

- First of all, one end of the plug is connected to the digital pin 8 of the Arduino, the other end is connected to the insertion plate;

- a pull-down resistor of $10 \mathrm{~K}$ is added to the insertion plate, one of its legs is connected to the end of the plug and the other to the common mass with the Arduino;

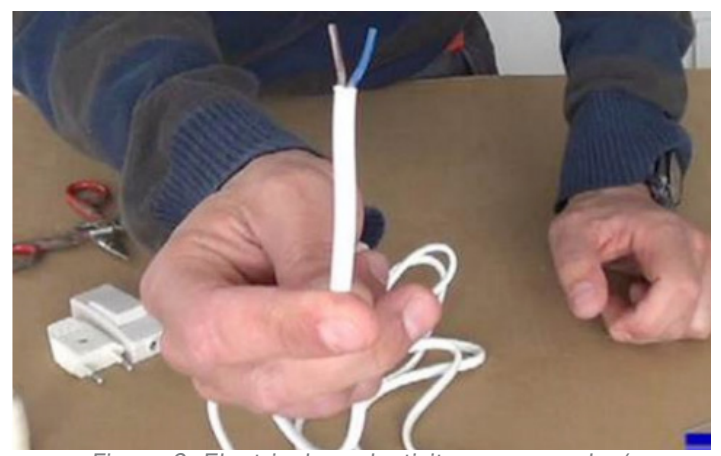

Figure 2. Electrical conductivity sensor ends / Extremos del sensor de conductividad electrica estos cables se conecta a un electrodo del enchufe, en un lado, y al Arduino en el otro extremo, de esta manera el enchufe funcionará como sonda en el agua y la información de la conductividad eléctrica podrá extraerse de los valores leídos en los cables. Lo único que habrá que añadir para la conexión son dos cables de Arduino para que los extremos sean compatibles con la placa.

Para su conexión con Arduino se han seguido las indicaciones dadas por Gertz y Di-Justo (2012). El resultado del conexionado es relativamente sencillo, como se puede observar en la Figura 3:

- en primer lugar se conecta uno de los extremos del enchufe al pin digital 8 de Arduino, el otro extremo se conecta a la placa de inserción;

- se añade una resistencia de pull-down de $10 \mathrm{~K}$ en la placa de inserción, una de sus patas se conecta al extremo del enchufe y la otra a la masa común con el Arduino; y

- por último, se conecta un cable desde el pin analógico de Arduino Al hacia la pata de la resistencia que está conectada al extremo del enchufe.

Para calibrar este sensor se han utilizado dos soluciones de calibración de la marca Hannah, una de $1.413 \mathrm{mS} / \mathrm{cm}$ y otra de $12.88 \mathrm{~ms} / \mathrm{cm}$. Consideramos lineal la función de calibración de la conductividad eléctrica en función del voltaje. Aunque se verá más tarde que esto no es del todo cierto, nuestras dos soluciones de calibración rodean justo el límite del agua potable, que está en torno a $10 \mathrm{mS} / \mathrm{cm}$, y el valor del agua destilada $(11 \mu \mathrm{S} / \mathrm{cm})$. Esto hace que donde se va a tener mayor precisión es en los valores límite. Una vez el límite superior se ha rebasado, ya no importa que la medida sea menos precisa pues el sistema detectará que el límite de potabilidad ha sido superado y disparará la alarma. Además, como la conductividad eléctrica solo tiene un límite superior de potabilidad (es decir, que si la conductividad es muy baja el agua es mejor), tampoco va a ser un problema que el módulo no sea capaz de detectar valores muy bajos de conductividad eléctrica porque eso indicaría que es de muy buena calidad. Esto resulta del objetivo de este proyecto, que no es estimar la calidad del agua, sino de poder diferenciar si el agua está en condiciones de ser bebida o no.

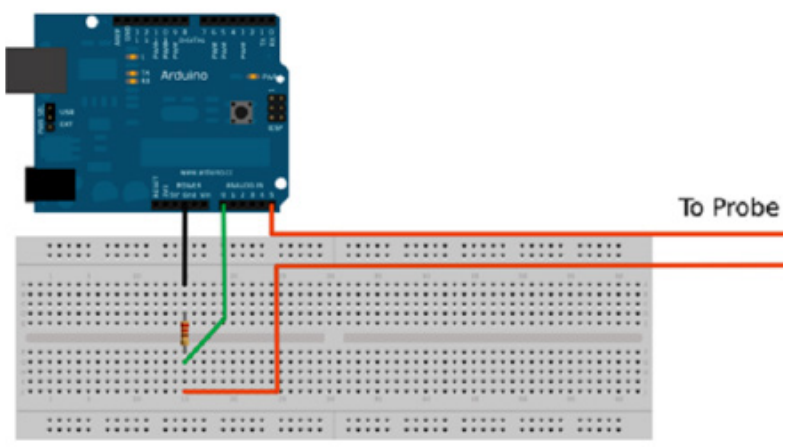

Figure 3. Connections of the electrical conductivity sensor with the microcontroller / Conexiones del sensor de conductividad eléctrica con el microcontrolador 
La metodología para estimar el nivel de las aguas y emitir criterios referentes a la posible inundación o desbordamiento de los caudales, está dado por la disposición de un número determinado de sensores de conductividad eléctrica a lo largo de una sonda cilíndrica conformada por dos tubos concéntricos. A medida que varía el nivel de agua, y de acuerdo con el número de sensores que estén midiendo la conductividad de esta, se podrá estimar entonces su altura aproximada (ver FIGURA 4).

\section{Módulo GPS/GSM A7}

Conjuntamente con la placa Arduino se acoplará este otro módulo para asegurar la comunicación con un centro de control y supervisión de los parámetros censados. Este consiste en un módulo GPRS/GSM/GPS (ver Figura 5), que soporta su operación en redes GSM/GPRS Quad-Band (850/900/1800/1900). Soporta, además, llamadas de voz, mensajería SMS, servicio de datos por GPRS y función GPS (Zhang, 2016)

La interconexión con la placa Arduino se realiza mediante comunicación serie UART, según se describe en la Figura 6.

La configuración del módulo, a través de software, se realiza mediante comandos AT (Zhang, 2016). Este es un set de instrucciones estándar para la comunicación y configuración de los microcontroladores. Por lo tanto, es una de las variantes óptimas para cubrir nuestras necesidades de comunicación con los servidores, para al almacenamiento de datos y el monitoreo de variables.

\section{Sistema completo}

Una vez realizada la descripción de los elementos que constituyen la aplicación propuesta, una representación general del mismo seria como se presenta en la Figura 7.

\section{Sonda}

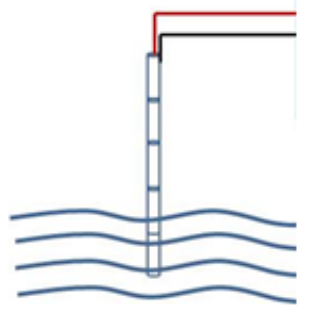

Figure 4. Conductivity and water level measurement probe / Sonda de medicion de conductividad y nivel del agua

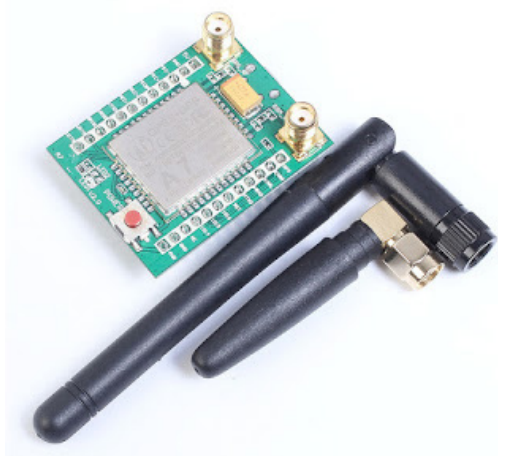

Figure 5. Module A7
- finally, a cable is connected from the Arduino Al analog pin to the leg of the resistor that is connected to the end of the plug.

To calibrate this sensor, two calibration solutions of the Hannah brand were used, one of $1.413 \mathrm{mS} / \mathrm{cm}$ and another of $12.88 \mathrm{mS} / \mathrm{cm}$. We consider as linear the function of calibration of electrical conductivity according to voltage. Although it will be seen later that this is not entirely true, our two calibration solutions surround the drinking water limit, which is around $10 \mathrm{mS} / \mathrm{cm}$, and the value of the distilled water $(11 \mu \mathrm{S} / \mathrm{cm})$. This means that where it is going to have greater precision is in the limit values. Once the upper limit has been exceeded, it no longer matters that the measurement is less precise because the system will detect that the potability limit has been exceeded and the alarm will trigger.

In addition, since electrical conductivity only has an upper limit of potability (that is, if the conductivity is very low, the water is better), it is not going to be a problem that the module cannot detect very low values of electrical conductivity because that would indicate that it is of very good quality. It results from the objective of this project, which is not to estimate the quality of the water, but to be able to differentiate if the water is able to be drunk or not.

The methodology for estimating the water level and issuing criteria regarding the possible flooding or overflowing of the flows, is given by the arrangement of a certain number of sensors of electrical conductivity along a cylindrical probe formed by two concentric tubes. As the water level varies and according to the number of sensors that are measuring the conductivity of the water, it will be possible to estimate its approximate height (see Figure 4).

\section{A7 GPS/GSM Module}

Together with the Arduino board this other module will be connected to ensure communication with a control and monitoring center of the parameters registered. This consists of a GPRS/GSM/GPS module, which supports its operation in GSM/GPRS Quad-Band networks (850/900/1800/1900). In addition, it supports voice calls, SMS messaging, data service by GPRS and GPS function (Zhang, 2016). The interconnection with the Arduino board is carried out through UART serial communication, as described in Figure 6.

The configuration of the module, through software, is carried out using AT commands (Zhang, 2016). This is a set of standard instructions for communication and 


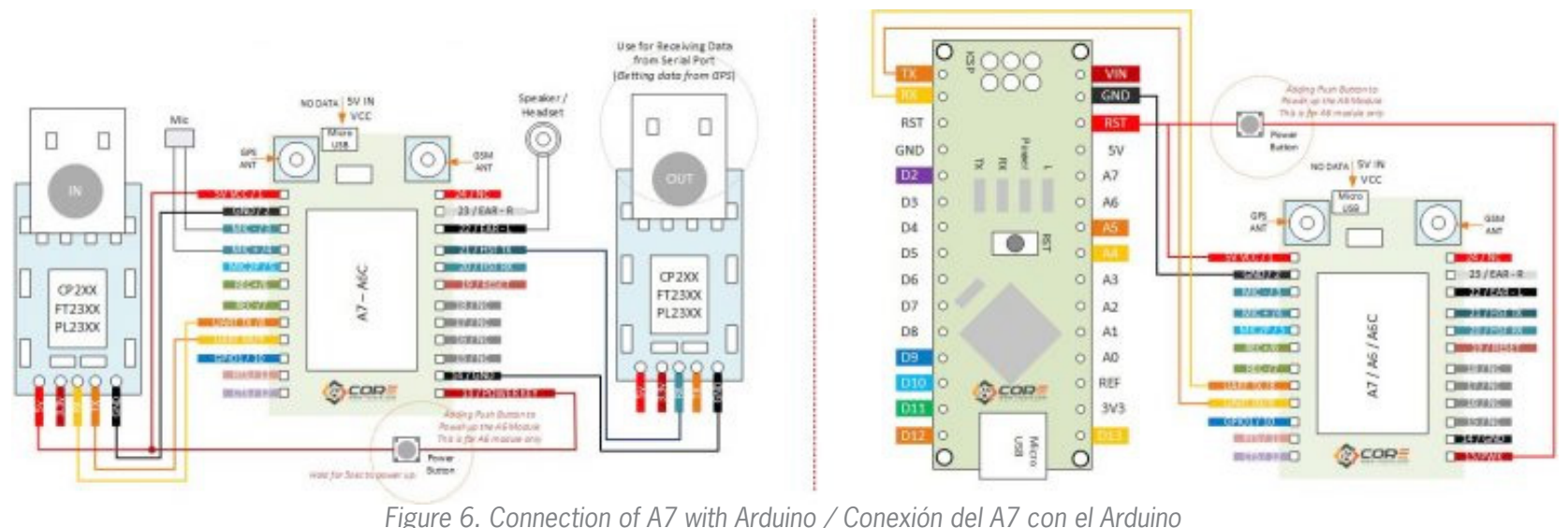

configuration of microcontrollers. Therefore, it is one of the optimal variants to cover our communication needs with servers, for data storage and variable monitoring.

\section{Complete System}

Once the description of the elements that constitute the proposed application has been made, a general representation of it would be as shown in Figure 7.

At the software level, the system, once energized, performs a check of the peripherals connected to Arduino. Once this is performed, it makes a capture of the GPS data to update the time and date, in order to elaborate an SMS notification that the system has started correctly; if not, it details the errors found. From here on, the system performs readings of the sensors and forms the messages with the values of the measured parameters, and then changes to a working mode of low consumption [sleep], until the next reading. Likewise, it is possible to order a manual reading of the sensors through the sending of an SMS to the system, which immediately changes to the usual working mode.

\section{Conclusions}

This project, focused in measure of water quality in distribution networks and reservoirs, and monitoring of behavior of the levels of natural water resources, has, undoubtedly, notable importance. The availability of information regarding the sensors implemented through the use of the mobile network with wide use, reliability and speed has been demonstrated. It has incorporated a system of alarms and notifications that allows an effective control and maintenance before any anomaly caused.

The government authorities of aqueducts and sewage systems can count with a management and contol of the components of their infrastructure tool; This way, it acts, at the same time, as feedback of the efficiency of the work carried out. ST

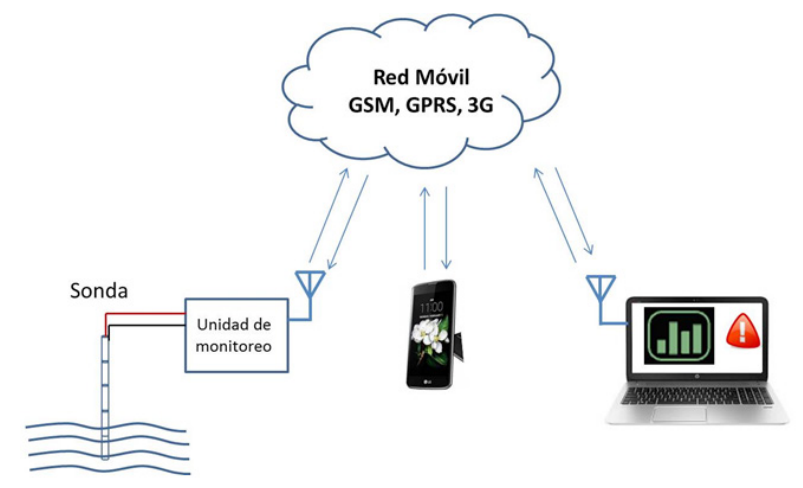

Figure 7. General diagram of the system / Esquema general del sistema

A nivel de software, el sistema, una vez energizado, realiza un chequeo de los periféricos conectados al Arduino. Una vez realizado esto, hace una captura de los datos del GPS para actualizar la hora y fecha, con el fin de elaborar una notificacion SMS de que el sistema ha iniciado correctamente; de no ser asi detalla los errores encontrados.

A partir de aquí, el sistema realiza lecturas de los sensores y conforma los mensajes con los valores de los parametros medidos, y despues cambia a un modo de trabajo de bajo consumo [sleep], hasta la próxima lectura. Asimismo, se puede ordenar realizar una lectura manual de los sensores, a través del envío de un SMS al sistema, lo que inmediatamente cambia al modo de trabajo habitual.

\section{Conclusiones}

La realización de este proyecto de medición de calidad de agua en redes de distribución y embalses, además del monitoreo del comportamiento de los niveles de los recursos hídricos naturales, reviste, sin lugar a dudas, de una importancia notable. Se ha demostrado la disponibilidad de la información relativa a los sensores implementados a través del uso de la red móvil con amplio uso, fiabilidad y rapidez. Se ha incorporado un sistema de alarmas y notificaciones que permite el efectivo control y mantenimiento ante cualquier anomalía ocasionada.

Las entidades rectoras de acueductos y alcantarillados pueden contar con una herramienta de gestión y contol de los componentes de su infraestructura; asi actúa, a la par, como realimentación de la eficiencia del trabajo realizado. $\mathbf{S}$ T 


\section{References / Referencias}

Arduino. (2018). Arduino Mega. Retrieded from: https://www.arduino.cc/en/Main/arduinoBoardMega

Gertz, E., \& Di Justo, P. (2012). Environmental Monitoring with Arduino. Sebastopol, CA: O'Reilly.

Organización Mundial de la Salud [OMS]. (2006). Guías para la calidad del agua potable: primer apéndice a la tercera edición, volumen 1, recomendaciones. Ginebra, Suiza: OMS.

VJ-Pixel (2017). Mãe d'Água. Retrieved from: https://publiclab.org/wiki/mae-d-agua

Warren, J. (2017). Riffle design philosophy. Retrieved from: https://publiclab.org/wiki/riffle_design_philosophy

World Heatlh Organization / United Nations Children's Fund [WHO / UNICEF]. (2015). Joint Monitoring Programme. Report 2. Geneve, Switzerland: WHO.

Zhang, E. (2016). A6/A7/A6C User Manual. Shangai, China: Al ThinkerTechnology. 


\section{CURRICULUM VITAE}

Armando Rodríguez Rodríguez Engineer in Telecommunications and Electronics from the University of Pinar del Río "Hermanos Saiz Montes de Oca" [UPR] (Cuba, 2017). He is a professor in the Department of Telecommunications and Electronics of the Faculty of Technical Sciences of the UPR since 2017. He has taught subjects related to analog electronics and power supplies. His research areas are: process automation, demotic control systems and fiber optic sensors / Ingeniero en Telecomunicaciones y Electrónica de la Universidad de Pinar del Río "Hermanos Saiz Montes de Oca" [UPR] (Cuba, 2017). Es profesor del Departamento de Telecomunicaciones y Electrónica de la Facultad de Ciencias Técnicas de la UPR desde 2017. Ha impartido asignaturas relacionadas con electrónica analógica y fuentes de alimentación. Investiga sobre automatización de procesos, sistemas de control demótico y sensores de fibra óptica.

José Raúl Vento Álvarez He was born in Pinar del Rio (Cuba) on November 25, 1958. He is a Telecommunications Engineer from the Instituto Superior Politécnico "José Antonio Echeverría" (CUJAE) (Havana, Cuba, 1982). He received his Master in Telecommunications Networks (1996) and his degree as Doctor of Telecommunications Engineering (1998) from the Universidad Politécnica de Madrid (Spain). He is a professor in the Department of Telecommunications and Electronics of the Faculty of Technical Sciences of the Universidad de Pinar del Rio since 1990. He has taught subjects related to telecommunications networks, telematics and optical communications and has been tutor of several degree projects (Engineering and Master and PhD in Telecommunications). His research areas of interest are: fiber optic sensors and control systems on the Internet of Things [loT] / Nació en Pinar del Rio (Cuba) el 25 de Noviembre de 1958. Es Ingeniero en Telecomunicaciones del Instituto Superior Politécnico "José Antonio Echeverría" (CUJAE) de La Habana (Cuba, 1982). Recibió su Máster en Redes de Telecomunicaciones (1996) y su grado como Doctor Ingeniero de Telecomunicación en la Universidad Politécnica de Madrid (España, 1998). Es profesor del Departamento de Telecomunicaciones y Electrónica de la Facultad de Ciencias Técnicas de la Universidad de Pinar del Rio desde 1990. Ha impartido asignaturas relacionadas con redes de telecomunicaciones, telemática y comunicaciones ópticas. Ha sido tutor de varios proyectos de culminación de estudios en Ingeniería y de la maestría y el doctorado en Telecomunicaciones. Investiga sobre: sensores de fibras ópticas y sistemas de control en Internet de las Cosas [loT].

Jorge Garrido González Engineer in Telecommunications and Electronics and Master of Science - New Technologies Applied to Education. He is an assistant professor at the Department of Information Technology of the Universidad de Pinar del Río "Hermanos Saiz Montes de Oca" (Cuba) and member of the Provincial Council of the Unión de Informáticos de Cuba (Pinar del Río). His areas of professional interest are: developing applications with C \# programming language, programming for Arduino devices and automated systems / Ingeniero en Telecomunicaciones y Electrónica y Máster en Ciencias - Nuevas Tecnologías Aplicadas a la Educación. Es profesor Auxiliar del Departamento de Informática de la Universidad de Pinar del Río "Hermanos Saiz Montes de Oca" y miembro del Consejo Provincial de la Unión de Informáticos de Cuba en Pinar del Río. Sus áreas de interés profesional son: el desarrollo de aplicaciones con lenguaje de programación C\#, la programación para dispositivos Arduino y los sistemas automatizados.

Vicente Rodríguez Benítez Telecommunications and Electronics Engineer from the Universidad de Pinar del Rio [UPR] (Cuba, 2011); and Master in Telecommunications Systems (2014). He is an assistant professor, responsible for the discipline of Electronics at the UPR. He teaches the subjects of Electronic Measurements, Electronic Simulation Tools and Mathematical Assistant for Engineering (Matlab). His lines of research are: digital signal processing, creation of automated systems (home automation and Internet of Things) on the Arduino platform, image processing and study and creation of new sensors for process control / Ingeniero en Telecomunicaciones y Electrónica de la Universidad de Pinar del Rio [UPR] (Cuba, 2011); y Máster en Sistemas de Telecomunicaciones (2014). Profesor asistente, responsable de la disciplina de Electrónica en la UPR. Imparte las asignaturas de Mediciones Electrónicas, Herramientas de Simulación Electrónica y Asistente Matemático para la Ingeniería (Matlab). Investiga en las líneas de: procesamiento digital de señales, creación de sistemas automatizados (domótica e Internet de las Cosas) sobre la plataforma Arduino, procesamiento de imágenes y estudio y creación de nuevos sensores para el control de procesos. 